Vol. XVIII No. 2

\title{
One-winged Ducks
}

by R. W. Nero, Saskatchewan Museum of Natural History

Occasional reports are heard of a hunter shooting a duck which has only one wing. Usually the hunter solemnly affirms that the duck was shot while flying but this can undoubtedly be attributed to facesaving. A question of interest is whether these are birds which have survived a major accident or whether they have a congenital deformity.

R. D. Caskey, for example, reports such an incident involving a drake Mallard (1950. A one-winged duck, Blue Jay, 8:28), stating: "I thought he had lost one wing and it wasn't until I had him dressed that I noticed he never had a second wing. The skin showed no scar and was perfectly smooth over the area where the wing should have joined the body... he was in prime condition." According to Caskey, when the duck was first approached it "got no more than six feet up and then coasted down." It seems incredible that a duck with only one wing could rise off the water at all, but it may be possible for an otherwise strong and vigorous duck to flap and spring a few feet into the air.

Two one-winged ducks have recently been received by the Museum. An adult male Blue-winged Teal (Anas discors) was found by Adolph Nishnik, Prince Albert, when he noticed it being attacked by a hawk at a large slough one mile east of Rosthern, Sask., in the latter part of September, 1958. It was submitted to us by Harold Read, Dept. of Natural Resources, Prince Albert. This bird was in fairly good shape, and at first glance looked as if it had never had but one wing. However, as suspected, this was a normal bird which had lost its left wing, presumably sometime during the year. Upon dissection, about an inch of the wing bone was found still attached to the shoulder joint. The broken end was partly but not completely closed by bony tissue and it was nicely rounded. A small amount of scar tissue on the surface of the skin overlying the broken bone provided further evidence on the recent nature of the injury.

The second duck was also a male
Blue-winged Teal, apparently an adult, which was shot on September 9, 1958, near Balgonie, Sask., by Larry Gnus and Brian Davies. This bird lacked a right wing and again there was a small and easily overlooked scar on the skin over the place where the bone would have protruded. About three-quarters of an inch of the broken humerus was found intact and in place, The broken end was sharper than in the other specimen and was covered by some connective tissues. This injury appeared to be even more recent than the other. However, the bird was very fat and appeared to be in good condition although the flight feathers of the remaining wing were badly worn and heavily frayed at the tips.

It seems clear that both of these birds lost a wing during the year as the result of an accident which broke the humerus close to the body or actually severed the wing. In some cases which I have observed of broken wings in various birds, the wing was almost completely severed by subsequent attempts to fly or move about. Also, birds are frequently found alive some time after a wing has been directly torn off. This is not an uncommon occurrence where shorebirds in large numbers encounter low telephone wires, and presumably the same accidents may befall fast-flying ducks like teal. Lyle K. Sowls mentions finding four dead drakes (species?) which were apparently killed by striking telephone wires at the Delta Marsh (1955. Prairie Ducks. Wildlife Mgt. Inst., Washington, D.C. p.116). No doubt there were others which struck the wires and survived, possibly even with the loss of a wing. Rapid healing of grave injuries is well known for birds, but the survival period of such victims is undoubtedly very short.

Several one-winged ducks have been received by the Museum in past years, including a male Mallafd, male Blue-winged Teal and a female Pintail. According to Fred W. Lahrman, those which were examined in detail showed conditions similar to the two described above. 